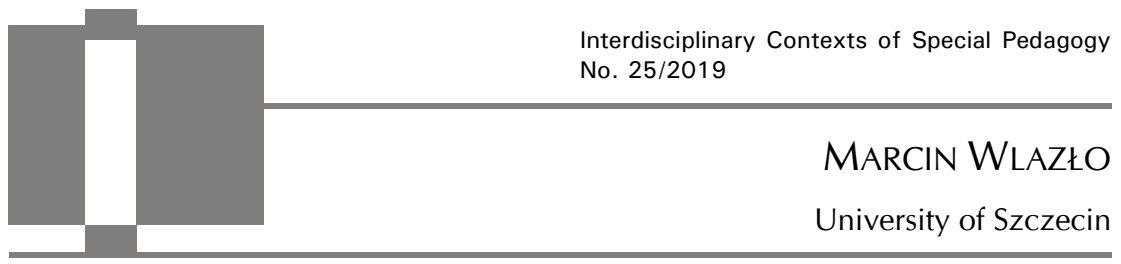

\title{
The economics of disability and the discourse of eliminating inequalities and providing equal opportunities
}

\begin{abstract}
Marcin Wlazło, The economics of disability and the dis-course of eliminating inequalities and providing equal opportunities. Interdisciplinary Contexts of Special Pedagogy, no. 25, Poznań 2019. Pp. 33-53. Adam Mickiewicz University Press. ISSN 2300-391X. DOI: https:/ / doi.org/10.14746/ikps.2019.25.02

Disability results in certain economic consequences, which are analysed mainly because of the generation of cost. The economic situation of people with disabilities and their families is usually associated with negative effects of neoliberalism, or causing and strengthening social inequality and excluding people unattractive on the market. In this context, the relationship between technological progress, economic growth and diagnostic and therapeutic services are also analysed. The article presents various aspects of the economic discourse focused on disability. The analysis is based on examples that consolidate the traditional image of disability as a factor affecting low economic status, through a description of the market of services and goods for people with disabilities, to examples of economic success achieved by people with disabilities.
\end{abstract}

KEY WORDS: economics of disability, inequalities, equalization of opportunities 


\section{Introduction}

Interest in the economic aspects of disability is integrally linked to the development of its social model, under which a category of economic barriers, listed next to environmental (physical) barriers as a separate element or part of broadly understood social barriers, has appeared. The new (social) expression (construction) of the problem of disability was associated not only with undermining the dominance of its traditional models (moral, medical, individual), but also with showing the variety of factors and the complexity of relationships that shape social reality and human functioning. Disability has become a subject of scientific interest going beyond medicine, inspiring equally social (including economic) and humanistic (cultural) research. Twentieth-century social theories, including particularly post-structural concepts that enabled the study of disability from a class (socioeconomic), racial (minority), feminist (intersectional), postcolonial (global) or cultural perspective, have proven to be powerful support for disability studies. By identifying the social model of disability with an interactive approach, Marcin Garbat has traced the historical conditions of including disability issues in economic theories. ${ }^{1}$ The most important finding is that the aforementioned author links the social model of disability with historical materialism and class perspective, which he does, referring to the precursor studies in this area of Vic Finkelstein, ${ }^{2}$ i.e. a researcher associated with both the introduction of the social model of disability and the development of academic disability studies. The personal involvement of people with disabilities in the struggle for their own rights has led to the initiation of changes whose basic direction has been set by historically and socioeconomically shaped slogans aimed at eliminating inequalities and providing equal opportuni-

${ }^{1}$ M. Garbat, Społeczny wymiar niepetnosprawności w teoriach ekonomii, „Studia Oeconomica Posnaniensia" 2017, vol. 5, no. 10.

2 V. Finkelstein, Attitudes and Disabled People, World Rehabilitation Fund, New York 1980. 
ties. Respecting civil rights in relation to all people has never been a matter of course or common practice, even in countries where social change (including revolutions) sanctioned anti-discrimination solutions.Disability is actually the last factor that commonly conditions socioeconomic inequalities, which have not completely disappeared even in the case of factors such as gender, race or social origin, which much earlier than disability became the cause of the fight for equal treatment.

Summarizing his historical and theoretical considerations, including Marxist tradition, institutionalism and protective capitalism, Garbat states that

Disability, despite a strong development of anti-discrimination laws and a change in the perception of people with disabilities, is still one of the main factors of poverty, and thus, stigmatization and social exclusion. It is even stronger because it directly affects a given person as well as indirectly their relatives, according to the assumptions of social systems responsible for helping a person with a disability. ${ }^{3}$

The subject of this paper includes selected examples of economics and disability discourse in media reports and journalistic texts. The analysis of this form of discourse allows for the presentation of both the current perception of disability as a factor strictly conditioning the economic situation of a large group of people (with disabilities and their families), as well as the state's social policy regarding the dissemination of standards (including economic ones) of eliminating inequalities and providing equal opportunities However, this is not a critical analysis of the discourse, but a contextual review of the thematic threads in the field of combining disability and economics. At the same time, the purpose of the undertaken analyses is to present the "economics of disability" present in the title, as a complex and ambiguous concept, whose proper meaning is in fact dependent on the effect of the discourse analysis and its contexts.

${ }^{3}$ M. Garbat, op. cit., p. 82. 


\section{"Whose life is the hardest?", 4 contexts of economics of disability}

The title of the report based on research conducted in July 2018 by the CBOS encourages reading the content of the study with its linguistic form. The question always stimulates curiosity, and a professionally prepared statistical summary is an important context for qualitative discourse analysis. In this case, information should be expected that would directly relate to the identification and arrangement of factors affecting "life difficulties" in the opinion of the respondents 5 , which the authors of the report associate with marginalization, exclusion, worse treatment and lower social acceptance of selected groups of people, which causes that they have fewer opportunities to satisfy their needs. ${ }^{6}$ The basic question asked to respondents was as follows: "Which of the mentioned groups, in your opinion, are in the worst situation and face the greatest difficulties and limitations in society?" Replying to it, the respondents could choose no more than three such groups. The highest number of indications was given to the disabled (43\%), then the poor $(37 \%)$ and the elderly $(27 \%)$. The mentioned survey has the value of a longitudinal study because it is a repetition of the study conducted 5 years earlier, in 2013. The comparison of the results of both studies illustrates a clear change in the respondents' perception of factors determining life difficulties. In 2013, the disabled received $28 \%$ of responses, the poor $53 \%$, while the elderly $28 \%{ }^{7}$ The exchange of positions between disability and poverty should

${ }^{4}$ See. Komunikat z badań CBOS, Komu żyje się najtrudniej?, no. 106/2018 (ed. by M. Omyła-Rudzka).

5 "The study "Current Problems and Events" („Aktualne problemy i wydarzenia") (338) was conducted by means of computer-assisted face-to-face interviews (CAPI) in the period from 28 June to 5 July, 2018 on a representative sample of 952 random adult Polish residents." After: Komunikat z badań CBOS, Кomu żyje się najtrudniej?, op. cit.

${ }^{6}$ See Ibidem, p. 1.

7 Ibidem, p. 8. 
not surprise in the context of the Polish economic situation in recent years, or steady economic growth, a decrease in unemployment, an increase in salaries and government family support programs. At the same time, it can be presumed that the participation of people with disabilities and their families in positive economic changes is small, and the combination of disability with the broadly defined mechanisms of social exclusion has been clearly strengthened and established.

In extensive quantitative studies on the global approach to disability and poverty, these phenomena are treated as interdependent, or they are a mutual cause and effect. ${ }^{8}$ However, problems associated with estimating the impact of disability on poverty level, including a situation when the issue of the economic functioning of households with people with disabilities is considered, are indicated. Referring to quantitative data from two countries (Bosnia and Vietnam) regarding the scale of poverty, and obtained on the basis of measuring the level of consumption and functioning of people with disabilities (according to the WHO ICF model), the authors of the mentioned study assumed that "ignoring disability significantly reduces the importance of both poverty and the impact of disability". 9

This opinion corresponds to the thought referred to by Michael Palmer ${ }^{10}$ in his review of theoretical assumptions common to the issue of poverty and disability: "The most dangerous and widespread threat to people with disabilities comes from a less dramatic, so widespread that increasingly less perceived source, poverty." 11 In

8 J. Braithwaite, D. Mont, Disability and poverty: A survey of World Bank Poverty Assessments and implications, "ALTER, European Journal of Disability Research" 2009, vol. 3, p. 230.

${ }^{9}$ Ibidem, p. 230. All translations from English were made by the author of the article.

10 See M. Palmer, Disability and Poverty: A Conceptual Review, "Journal of Disability Policy Studies" 2011, vol. 21, no. 4.

11 A. Ghai, Marginalization and disability: Experiences from the Third World. In M. Priestley (ed.), Disability and the life course, Cambridge University Press (pp. 26-37). Cambridge 2001, p. 28. 
the study of the Australian researcher, the issue of the cost of disability was raised as not only an economic problem, but also an unambiguous association established in the public consciousness, which has the effect of specifically expanding the area of the negative, medical image of disability to include economic helplessness, unproductivity and constant reporting on financial support needs. Palmer postulates clarifying the definition of poverty in the context of disability, noting the differentiation of consequences depending on the adopted concept of poverty. Namely, he proposes that the economic situation of people with disabilities should be analysed in the context of three definitions of poverty, based in on an approach considering basic needs, capabilities and economic resources, respectively. Only the combination of aforementioned factors creates the possibility of a full overview of the relationship between disability and economic situation, which has also been reflected in the latest models of studies on disability, postulating a departure from analyses focused exclusively on the situation of people with disabilities in the rich countries of North America and Europe and expanding disability studies by global South studies. In this approach, disability is associated with the historical consequences of colonialism, which results the interdependent phenomena of a greater number of people with disabilities in former colonies and the structural economic exclusion of countries, whose human and material resources had been exploited for years. ${ }^{12}$

The problems of developed countries are, in turn, reduced to the consequences of neoliberal politics and economics, under which disability becomes both a cause of socioeconomic exclusion and an object of market formatting in the context of the offer of services and goods. Goodley says directly:

12 Zob. M. Miles, Disability on the Different Model. Glimpses of an Asian Heritage, "Journal of Religion, Disability and Health" 2002, vol. 6, no. 2-3, pp. 89-108; A. Ghai, Disabled Women: An Excluded Agenda of Indian Feminism, "Hypatia" 2002, vol. 17, no. 3, pp. 49-66; A. Ghai, Marginalization and disability: Experiences from the Third World, op. cit. 
People with disabilities may suffer from socioeconomic difficulties. In rich countries, people with disabilities are economically threatened by the expansion of the free market, population growth, the scale and professionalization of social and educational services, as well as growing needs for "intellectual ability" and "physical ability" to work. ${ }^{13}$

In Polish literature no less radical approaches to this issue can be found. Namely, Aleksander Lipski writes about the "problem of disabled people under the conditions of the discourse of neoliberal economics"14, from the position of an economist convincing readers on the basis of the examples that

therefore, the issue of social environments such as people with disabilities, hence to a certain extent and sense excluded and marginalized in the social system, covers not only their commonly known psychophysical concerns and problems, but also the much less frequently perceived problem of their state of consciousness and their ability to analytically and critically interpret reality. ${ }^{15}$

The cited text draws attention to the paradox of emancipation by marketization of one's own body, which the author illustrates by a specific situation of women with disabilities taking part in beauty contests, modelling, advertising or dance tournaments. Referring, on the one hand, to the dominance of neoliberal ideology, and on the other hand, to the discursive categories of dramatization and aestheticization of reality, and especially the power-knowledge of Michel Foucault, Lipski combines the "axionormative order of modern society" with "adaptive and integration programs" identified with "symbolic violence of the social system". 16 The aestheti-

13 D. Goodley, Disability Studies: An Interdisciplinary Introduction, Sage Publications Ltd., London 2011, p. 2.

14 A. Lipski, Problem osób niepetnosprawnych w warunkach dyskursu ekonomii neoliberalnej, "Problemy Edukacji, Rehabilitacji i Socjalizacji Osób Niepełnosprawnych" 2018, vol. 27, no. 2, pp. 29-59.

15 Ibidem, p. 55.

16 Ibidem, 30-37. 
zation of disability is an increasingly obvious example of the development of ableist hegemony, for which normality is no longer sufficient, because on the market it is necessary to constantly raise standards and set trends that are difficult to achieve also for ablebodied people. ${ }^{17}$ In this context, the intersectional complexity of the situation of women experiencing the socioeconomic consequences of disability as a result of damage to the body of their own or their children is significant. Referring to the voluntary and even desired aestheticization and marketization of the body, Lipski states:

The most striking and paradoxical at the same time in this procedure is not the practice of using women as these cultural products itself, but the fact that its participants themselves contribute to its maintenance and consolidation. As they confess, this situation not only does not bother them, but is even convenient for them, which is related to the shared responsibility attributed by Fraser to feminist movement representatives for the failure of its original program contesting discrimination of the weaker and social inequalities in the neoliberal social system. Therefore, by accepting and including the process of objectification and instrumental use as aesthetic exhibits, its participants themselves strengthen the neoliberal economic order. ${ }^{18}$

The presented position seems to be accurate, although in such complex issues there can always be some doubt when the key issues of feminism and disability are presented, even on the basis of convincing analytical arguments, from the perspective of an ablebodied man, which must be faced also by the author of this text. Therefore, the discourse analysis presented below will not be, as according to methodological principles it cannot be, free from author's subjectivity, which can be both a strengthening and cognitive limitation of the presented postulates.

17 Zob. D. Goodley, Dis/ability studies. Theorising ablism and disablism, Routledge, London 2014, pp. 21-34.

18 A. Lipski, Problem osób niepetnosprawnych w warunkach dyskursu ekonomii neoliberalnej, op. cit., p. 54 . 


\section{Object and subject in the economic discourse of disability}

In the analysis of the economic and media discourse of disability, the starting point is invariably the combination of disability and cost generation. The economic situation of a family with a child (children) with disabilities, adults with disabilities and the elderly seen from the angle of the gradual loss of psychophysical fitness, is clearly associated with the support system as a social response to the needs that selected groups of people are not able to satisfy only by their own efforts. In the general social dimension, it is important to what extent support contributes to building social cohesion and to what extent it can cause disintegration phenomena. Social cohesion is associated with economic discourse, as it is defined (by the Council of Europe in operational terms) as "the ability of modern society to ensure long-term well-being for all its members, including equal access to resources, respect for human dignity and diversity, personal and collective autonomy and responsible participation"19 In such a definition, the inclusion of economic issues in the global dimension of social policy, constituting not only the expression of certain theoretical assumptions, but also directly implemented by political groups in power at a given time and place, is clearly visible.

In turn, the issue of the disintegrative nature of support is associated with disregarding the principles that are aptly characterised by John Rawls' theory of justice. ${ }^{20}$ It is primarily related to the second principle of justice, called the difference principle, according to which the overriding principle of equality (social and economic) can be suspended only if the most disadvantaged (according to Rawls) benefit. ${ }^{21}$ In practice, this always means that eliminating inequalities

${ }^{19}$ After: K. Wojnar, Wptyw polityki spójności na spójność społeczna polskich miast wnioski z badań ewaluacyjnych, "Studia Regionalne i Lokalne” 2011, special edition, p. 71 .

20 See J. Rawls, Teoria sprawiedliwości, translated by M. Panufnik, J. Pasek, A. Romaniuk, the translation was reviewed and completed by S. Szymański, Wydawnictwo Naukowe PWN, Warsaw 2009.

${ }^{21}$ Ibidem, p. 107. 
must be combined with providing equal opportunities. Polish analyses devoted to this issue clearly indicate that support, implementing by assumption the difference principle, can also be a cause of social disintegration, because:

1. It was revealed that there is a relatively frequent lack of social support in the environments covered by the study (unemployment, addictions, old age, disability).

2. Help is more available to those less in need.

3. People seek help and receive support to guarantee the satisfaction of their important needs more often in informal circles, mainly in the family, than in institutions established to help those in need. ${ }^{22}$

In the discourse presenting practical aspects of the location of people with disabilities (divided into the discourse of parents of minor and adult children with disabilities, adults with disabilities themselves and economists cooperating with non-governmental organizations) in the network of economic support, the disintegration effects of violating the principle of eliminating inequalities and providing equal opportunities can be easily perceived. An example of such discourse can be reportage presenting the everyday functioning of children with disabilities from the perspective of their mothers. A similar way of presenting economic issues can be seen in both shorter press forms ${ }^{23}$, and in extensive book materials. ${ }^{24}$ Namely, the pattern of combining reports on the personal economic situation with reference to the political and social conditions of the support system is repeated. In a short text from "Wysokie Obcasy" one can read:

What has recently happened in the government is one great hypocrisy. This refers to each party. All politicians go on populist slogans. They promise: "When we get the power, everything will change." What has

22 J. Grotowska-Leder (ed.), Sieci wsparcia społecznego jako przejaw integracji $i$ dezintegracji społecznej, Wydawnictwo Naukowe UŁ, Łódź 2008, p. 7.

23 See Z. Bukłaha, Ciesza mnie małe rzeczy, "Wysokie Obcasy” 2018, no. 37(1000), pp. 22-24.

24 See J. Hołub, Żeby umarło przede mna. Opowieści matek niepetnosprawnych dzieci, Wydawnictwo Czarne, Warsaw 2018. 
ever changed? Nothing, but people started talking about it. I do not feel the solidarity. All the more, even among parents of disabled children divisions are created. This is because of the ineffective system. At the beginning we were like children in the fog, we did not know that there were some foundations, that we could ask for immediate support. Now I get 1,470 PLN of attendance benefit that is spent on living. This is the payment for our work with the child. And even with that we have a good situation, because there are guardians of the disabled who get 520 PLN. In addition, 153 PLN of allowance for rehabilitation and medicines. (...) All that remains is the frustration and humiliation of mothers and fathers who work very hard to survive. ${ }^{25}$

In Jacek Hołub's reportages with extensive biography, a similar pattern is included in each of the five stories presented in the book. In one of the cases, the impact of communication is strengthened by the fact that the mother of a disabled child is disabled herself (congenital absence of forearm), raises her daughter alone and works professionally, so she cannot receive child benefits.

I do not get any help from the state. I am not a mother having an attendance benefit, but a mother with salary. I get 153 PLN a month of attendance benefit for myself, because I am disabled and 153 PLN for my disabled child. This is all the support that a disabled working mother receives from the state, raising a disabled child alone. ${ }^{26}$

At the same time, "stories of mothers of children with disabilities" testify to both the limitation of public finances in the field of eliminating barriers (providing equal opportunities) and the neoliberal excess of goods and services formatted for a consumer group, which is very sensitive in this regard, namely parents of children with disabilities.

This year I started to apply for a subsidy to remodel the kitchen, but we know what it is like: in the district 140,000 PLN was given for the

25 Z. Bukłaha, op. cit., p. 23.

${ }^{26}$ J. Hołub, op. cit., p. 92. 
so-called removing barriers and there are 70 applications. This has nothing to do with the needs. ${ }^{27}$

I go with Jagódka to an osteopath. Rehabilitation supposedly consists in the fact that by touching the appropriate organs and points on the child's body, the flow of cerebrospinal fluid is unblocked. When I started reading about it, I immediately gave it up, as I did not want to think that it was complete nonsense. Of course, the therapy is private, we pay 150 PLN for twenty minutes. I thought that I would give it a try, I bought ten treatments and we will see. A drowning man will clutch at a straw. There are a lot of tricksters, but I believe that someone will help Jagoda. ${ }^{28}$

The use of biographical reportage is a frequent journalistic procedure, which aims to present the current social problem based on the life history of a person who meets the assumed criteria. The issue of the economic situation of mothers-pensioners, who have looked after a disabled child for several dozen years, is thus illustrated by a specific case and its reference to thousands of analogous ones.

Jola is angry that the state treated her so unfairly. Her and 46,000 other parents, mainly women, who in the 1990s due to taking care of seriously ill children went on earlier but earned EWK pension (the name comes from the code of benefit according to Social Insurance). - We didn't give the children to an institution so that the state maintained them. We had drudged for 20 years to maintain them. When I lacked 5 months to 20 years, I cleaned the clinic at night, because I would not get anything. And today we have 600-700 PLN. And younger mothers who did not work for the sufficient number of years, but have quit their job to look after their ill child, get 1,300 PLN of attendance benefit. Is that fair? - she asks. ${ }^{29}$

The rhetorical use of numbers is particularly meaningful in economic discourse, and numerous journalistic texts focused on the

27 Z. Bukłaha, op. cit., p. 24.

28 J. Hołub, op. cit., p. 91.

${ }^{29}$ L. Anannikova, Gdyby leżat, toby nie żyt, „Duży Format” 2016, no. 38(1201), p. 22. 
subject of disability are based on the scheme of presenting the disproportion between needs and economic possibilities. In this way, the traditional image of disability, which is much closer to the individual and medical model than the social one, is strengthened (probably also against the intentions of discourse creators). This also happens when the parental criticism of the system has a constructive dimension, as in this quote:

The disabled care system must be rebuilt. How? Officials and social workers should support such families. Maybe a legal way to earn some money would be a good idea? Within certain frames, so as not to fall out of the market. And a list of institutions and places that can help. And we err, abandoned with our tragedy. ${ }^{30}$

Adults with disabilities often become co-authors of the discourse, which finds its fullest expression in the form of a press interview. The interview with Karolina Hamer, a Paralympic player, is a review of personal experiences, which from the perspective of a person with a disability constitute an accumulation of factors sanctioning inequality and discrimination. There are not many purely economic threads in this interview, but more important is that they appear as an important element in the description of the oppressive system, which the co-author of the discourse experiences intersectively as a bisexual woman, a sporstwoman with disability, taught and accustomed to constantly adapt to ableist-neoliberal mechanisms.

Before I decided to officially support the protest, I wondered for three days if this issue also concerned me. I am so used to patching up and adding resources to my disability that I could not see it right away. I was a victim of the belief that I must patch up everything myself. And now I think that the role of the state, however, is based on supporting people with disabilities. And we are talking here not only about dignity, but also about providing equal opportunities. As a woman close to forty years old, I am tired of having to organise everything myself, and

30 Z. Bukłaha, op. cit., p. 23. 
of always having to prove something. I would love to live peacefully. Sometimes. From the age of $20 \mathrm{I}$ add 1,500 PLN a month to have a living standard of a fully able-bodied person. Hence my full support for the protesters. ${ }^{31}$

Strengthening the critical assessment of the economic situation of people with disabilities is a feature of the discourse, whose coauthors are people who are able-bodied, but combine in their professional and social activity economic knowledge and knowledge of the reality of everyday functioning of people with disabilities with a direct commitment to changing the adverse dimensions of these reality. Information presenting the person with whom the interview is conducted, who is not necessarily a well-known person, such as Anna Dymna or Jerzy Owsiak, is an important component of the discourse, which in the case of conversation is always co-created by all participating people. Therefore, following a particular discourse also enables the identification of journalists in the context of the thematic area with which they associate their activity in the field of discourse production. Within such a framework, it is therefore necessary to analyse. for example, an interview with Paweł Kubicki ("economist, works at the Warsaw School of Economics; a collaborator of non-governmental organizations working for the elderly and the disabled, including the group We Want All Life (Chcemy całego życia)"), 32 which was conducted by Ludmiła Anannikova, dealing with social issues, especially the marginalization and exclusion of disadvantaged groups, and Justyna Suchecka, who writes primarily about broadly understood education. The starting point of the conversation is the recurring issue of raising funds from one percent of tax in annual cycles, which triggers the critical potential of the external and at the same time professional view of this issue. In the economist's statement, a differently expressed view revealed both in

31 Wyptywam na głębokie. Interview of Karolina Domagalska with Karolina Hamer, „Wysokie Obcasy” 2018, 21(984), p. 14.

32 Nasz jeden procent wyręcza państwo, Ludmiła Anannikova and Justyna Suchecka interview Paweł Kubicki, „Gazeta Wyborcza” 2018, no. 87(9301), p. 18. 
the confessions of parents of children with disabilities quoted earlier and in the conclusions of sociological research on support, can be found.

First of all, people who collect do not enjoy it at all. Many people perceive this as begging. Nicely packaged, colourful, smiling, but still begging. Begging, even when it comes to their child's health, is humiliating for most parents. We have created a system in which one has to abase oneself to get the support that in theory as taxpayers and citizens we should have.

This is "disability porn". To receive more, one should get rid of almost all privacy, one's own or of the child. (...) And additionally this "disability porn" destroys solidarity, a certain community of suffering. It turns even a tragic disease in which we should support each other turns into competition.

(...) The state is obliged to this help. After all, we pay contributions to receive support in a crisis situation. The social security system is based on such a promise. And in reality, when we are really on the razor's edge, it is not enough that we face pain, fear, life problems, as we also have to organise ourselves, obtain funds for rehabilitation, coordinate the collection of funds.

Those who succeed should not be treated as losers, and often this is how illness or disability is perceived, but as effective entrepreneurs. ${ }^{33}$

A similar scheme of analysis should also be adopted for the second example ${ }^{34}$; in this case, the interview was given by Maciej Augustyniak, the able-bodied founder of the Poland without Barriers (Polska bez Barier) foundation, and the interview was conducted by Ewa Wołkanowska-Kołodziej, a journalist interested mainly in social issues, especially in the social approach to old age, illness and disability. The conversation concerned multiple aspects of the exclusion of people with disabilities, and economic issues were the leitmotif of criticism focused on disregarding this social group of

${ }^{33}$ Ibidem, p. 18.

34 See Do nas tacy nie przychodza, Ewa Wołkanowska-Kołodziej interviews Maciej Augustyniak from the Poland without Barriers (Polska bez Barier) foundation, „Duży Format” 2018, no. 6(1271), pp. 20-22. 
people in organizing public space, including the one that should assume compliance with equality principles of universal design and thoughtful spending of public money. At the same time, the language itself as the material of discourse deserves attention, being in this case in its bluntness and even vulgarity, not only an element of the speaker's characteristics, but also an expression of probably a more general need to name specific issues literally and bluntly.

I have a biting tongue. I can accuse an official of both the lack of competence and the ambition to increase this competence.

It drives me crazy that public money is spent on things that are not available to everyone.

E.g., in Warsaw, a wheelchair user can get into the Museum of the History of Polish Jews, but not through the main entrance, but from the side where there is no automatically opening doors.

In turn, at the Copernicus Science Centre in Warsaw, a person with visual impairment can smash their heads on protruding things. And the award-winning Szczecin Philharmonic? Everyone is delighted, and no one pays attention to such bullshit that a person of short stature or a wheelchair user will not deliver the jacket to the cloakroom because the counter is too high. We head towards high technology, it costs tons of money and the stupid fragment of the countertop could not be lowered? Good architecture should serve everyone. ${ }^{35}$

The quoted statement opens several important thematic fields that contribute to the discourse built around the economic position of people with disabilities. These topics are bound by the slogan of accessibility, which on the one hand is a matter of changing attitudes towards key postulates of eliminating inequalities and providing equal opportunities, while on the other hand, concerns the economic and social dimensions of subjectivity in everyday relationships. Real empowerment is the opportunity to participate in making decisions that bind the private and public spheres. In this sense, arranging one's own room (apartment) to live comfortably and creatively (if this space is also a workplace) is the result of simi-

35 Ibidem, p. 20. 
lar decisions and proportional financial outlays as in the case of the design of public space, which by assumption is open and accessible to everyone.

The situation when the main creator of the discourse is a disabled person, can be considered an example of gaining subjectivity, especially when they act as an expert, e.g. in the field of modern technologies and business activities. A rather specific example is the article published in the weekly "Wprost", whose author is Adrian Furman, a disabled person, "The creator and president of the AF group, providing services related to modern technologies. It employs 30 people, including 23 with disabilities. He also has a company in the USA. One of the originators of the Accessibility plus (Dostępność plus) program". ${ }^{36}$ The specificity of this example is related to the fact that the weekly "Wprost" is a liberal-conservative periodical, and therefore it does not include a critique of the free market or capitalism, which is why also disability appears in its pages as part of a typical model of the neoliberal economy. Therefore, paradoxically, although in fact it is obvious in this case, the economic subjectivity of people with disabilities has been revealed in the context of market success already achieved or expected. Therefore, the following beginning is not surprising: "We live in times when disability does not have to mean poverty or helplessness.It can even motivate". ${ }^{37}$ The quasi-economic example of Nico Vujicic, a motivational speaker without arms and legs, is accompanied by the first of Furman's numerous examples based on measurable numerical value: "Another example is John Cronin's company. The man with Down syndrome came up with a brilliant idea of producing personalized socks with a unique design. And he personally promoted his company. In 2017, it had over 2 million dollars of revenue. This is an example of a business with a measurable financial result, carrying a message and social values that cannot be overestimated". 38

\footnotetext{
36 A. Furman, Niepetnosprawni na eksport, „Wprost” 2019, no. 13, pp. 46-47.

37 Ibidem, p. 46.

38 Ibidem, p. 46.
} 
In the analysed text, the government program "Accessibility plus" ("Dostępność plus") was compiled with the presentation of successes achieved by Polish startups, "related to the environment of disabled people". Therefore, technological projects such as Migam (application for people with hearing impairment), ParrotOne (communicator for people with hand dysfunctions), Blumil (trekking trolley for people with mobility disabilities), WalkinVR (virtual reality technology for people with motor limitations) have been listed. ${ }^{39}$ People with disabilities appear in these projects both as their originators and as the main recipients of goods and services created with full business understanding of market opportunities. The neoliberal narration has been extended to include a description of the government program, which is associated with the concept of smart money. The future of the business ventures of people with disabilities, compiled with market rules concerning all entrepreneurs, depended on properly formatted support.

However, there is something missing: capital and mentoring support. No two ways about it, to go beyond the design phase, more funding rounds are needed. (...) And here we come to what is necessary, i.e. building an investment fund for business environments of people with disabilities. A similar system solution is similar to the one proposed by the government by launching the "Accessibility plus" ("Dostępność plus") program. (...) Now it is time to go further. And this is not about easy access to money, it is just about smart money. That is, subsequent investment rounds that allow the movement from concept to the development of a full value product or service. ${ }^{40}$

The author of the last of the analysed texts perceives the image benefit that comes from promoting the business activity of people with disabilities, which significantly contrasts with the image of financial dependence, global poverty, "begging", competition for greater suffering, support reduced to constant dependence on bene-

\footnotetext{
39 Ibidem, p. 47.

40 Ibidem, p. 47.
} 
factors and donors. Examples of economic successes of people with disabilities can be perceived in the context of libertarian optimism, which is reflected in the book published in 2011 by Matt Ridley, a British economic journalist, businessman and science promoter, entitled "The Rational Optimist: How Prosperity Evolves". ${ }^{41}$ This book is an objection to the catastrophic generalization of reports on the scale of poverty, hunger, social exclusion or biological threats as information that dominates not only in media coverage but also scientific studies. Expecting the worst and pessimism cannot stand the confrontation with data on a positive change in the quality of life in terms beyond the experience covering even one generation. Moreover, a broader view of the history of mankind creates the opportunity to determine growth factors of prosperity, and these include primarily a human tendency to exchange not only ideas (thoughts), but also goods and services. The Ridley's optimistic vision assumes that "cultural development accumulated and rushed forward, initiating economic development", and "exchange is to cultural evolution as sex is to biological evolution". ${ }^{42}$

\section{Summary}

The presented examples of economic aspects of the media discourse of disability are connected by the issue of systemic removal of barriers and providing equal opportunities. Even such a brief review revealed, however, differences that depend on consent to include disability in market mechanisms, which places people with disabilities and their families, as well as institutions acting on their behalf, in economically diversified positions of aid beneficiaries, desired customers or innovative entrepreneurs and employers. Therefore, the economics of disability remains a vague and ambigu-

${ }^{41}$ M. Ridley, The Rational Optimist: How Prosperity Evolves, Fourth Estate, London 2011.

42 Ibidem. 
ous term, and even internally contradictory, but definitely more often associated with the huge costs of everyday functioning and socio-professional exclusion, than with market attractiveness or economic success, which are entangled in the neoliberal context which is always dangerous in the case of disability.

\section{Bibliography}

Anannikova L., Gdyby leżat, toby nie żyt, „Duży Format” 2016, no. 38(1201), p. 22.

Braithwaite J., Mont D., Disability and poverty: A survey of World Bank Poverty Assessments and implications, "ALTER, European Journal of Disability Research" 2009, vol. 3, pp. 219-232.

Bukłaha Z., Ciesza mnie małe rzeczy, „Wysokie Obcasy” 2018, no. 37(1000), pp. 22-24.

Do nas tacy nie przychodza, Ewa Wołkanowska-Kołodziej interviews Maciej Augustyniak from the Poland without Barriers (Polska bez Barier) foundation, „Duży Format” 2018, no. 6(1271), pp. 20-22.

Finkelstein V., Attitudes and Disabled People, World Rehabilitation Fund, New York 1980.

Furman A., Niepetnosprawni na eksport, „Wprost” 2019, no. 13, pp. 46-47.

Garbat M., Społeczny wymiar niepetnosprawności w teoriach ekonomii, „Studia Oeconomica Posnaniensia" 2017, vol. 5, no. 10, pp. 63-84.

Ghai A., Disabled Women: An Excluded Agenda of Indian Feminism, "Hypatia" 2002, vol. 17, no. 3, pp. 49-66.

Ghai A., Marginalization and Disability: Experiences from the Third World, in: M. Priestley (Ed.), Disability and the life course, Cambridge University Press, Cambridge 2001, pp. 26-37.

Goodley D., Disability Studies: An Interdisciplinary Introduction, Sage Publications Ltd., London 2011.

Goodley D., Dis/ability studies. Theorising ablism and disablism, Routledge, London 2014.

Grotowska-Leder J. (ed.), Sieci wsparcia społecznego jako przejaw integracji i dezintegracji społecznej, Wydawnictwo Naukowe UŁ, Łódź 2008.

Hołub J., Żeby umarto przede mną. Opowieści matek niepetnosprawnych dzieci, Wydawnictwo Czarne, Warsaw 2018.

Komunikat z badań CBOS, Komu żyje się najtrudniej?, no. 106/2018 (ed. by M. Omyła-Rudzka).

Lipski A., Problem osób niepetnosprawnych w warunkach dyskursu ekonomii neoliberalnej, "Problemy Edukacji, Rehabilitacji i Socjalizacji Osób Niepełnosprawnych” 2018, vol. 27, no. 2, pp. 29-59. 
Miles M., Disability on the Different Model. Glimpses of an Asian Heritage, "Journal of Religion, Disability and Health" 2002, vol. 6, no. 2-3, pp. 89-108.

Nasz jeden procent wyręcza państwo, Ludmiła Anannikova and Justyna Suchecka interview Paweł Kubicki, „Gazeta Wyborcza” 2018, no. 87(9301), pp. 18-19.

Palmer M., Disability and Poverty: A Conceptual Review, "Journal of Disability Policy Studies" 2011, vol. 21, no. 4, pp. 210-218.

Rawls J., Teoria sprawiedliwości, translated by M. Panufnik, J. Pasek, A. Romaniuk, the translation was reviewed and completed by S. Szymański, Wydawnictwo Naukowe PWN, Warsaw 2009.

Ridley M., The Rational Optimist: How Prosperity Evolves, Fourth Estate, London 2011.

Wojnar K., Wpływ polityki spójności na spójność spoteczna polskich miast - wnioski $z$ badań ewaluacyjnych, "Studia Regionalne i Lokalne” 2011, special edition, pp. 67-83.

Wyptywam na głęokie. Interview of Karolina Domagalska with Karolina Hamer, „Wysokie Obcasy” 2018, 21(984), pp. 10-15. 